\author{
VOLODYMYR ROMANTSOV, \\ Mariupol State University (Mariupol, Ukraine) \\ e-mail: romantsov_v@ukr.net, ORCID 0000-0002-9019-4149 \\ NATALIA ROMANTSOVA, \\ Mariupol State University (Mariupol, Ukraine) \\ e-mail: romantsova_n@ukr.net, ORCID 0000-0001-5032-1097
}

\title{
POLITICAL EVERYDAY LIFE OF MARIUPOL UKRAINIANS IN THE REVOLUTIONARY PROCESSES OF 1917 ON THE MATERIAL OF PERIODICALS
}

\begin{abstract}
The article highlights the issue of political everyday life of Mariupol Ukrainians in the revolutionary processes of 1917 on the basis of the analysis of periodicals. The informational and organizing role of the regional periodicals of that time, that, along with other aspects, contained reports on the political situation in Ukraine, the activities of Mariupol Ukrainians and the political influence on them by the Ukrainian Central Rada, have been emphasized. An analysis of the political everyday life of Mariupol Ukrainians in the revolutionary processes of 1917 makes it possible to determine the peculiarities of this social phenomenon. The change of vectors of everyday life of Mariupol Ukrainians in the political sphere during 1917 under the influence of revolutionary processes have been traced. It has been proved that the political everyday life of Mariupol Ukrainians in the rapid events of the revolution was determined by the influence of several factors: the Ukrainian Revolution, which began in 1917 as part of the Russian democratic revolution and after the adoption of the Third Universal, received a national character; the struggle for the revival of Ukrainian statehood, which was legally documented by the Universals of the Central Rada; active formation of Ukrainian identity at the regional level, social attitude in Ukraine in general and the Northern Azov and Mariupol; worsening of social contradictions and intensification of military and political confrontation at the end of the year. The place of activists of the Ukrainian movement in Mariupol in the political life of the revolutionary period has been defined.
\end{abstract}

Keywords: political everyday life; everyday life; Mariupol Ukrainians; periodicals.

\section{Introduction}

Observing the contemporary everyday life of Ukrainians, you unwittingly pay attention to how politicized our daily occurrence is. This observation results in searching for historical analogies. They can be easily found by investigating the revolutionary processes that took place during 1917 in Mariupol. In the history of Ukraine in general and Mariupol in particular it was a year special for intense political events and changes in a vector of social development. An analysis of the political everyday life of Mariupol Ukrainians in the revolutionary processes of 1917 allows to identify the peculiarities of this social phenomenon.

Ukrainians have historically constituted a large part of the population of the Northern Azov region and its center, Mariupol. The revolutionary processes of 1917 for the first time gave them the opportunity to participate in the political life of the region, which was a border region of Ukraine, for implementation of their national interests. The regional periodical played an important role in the political everyday life of Ukrainians in Mariupol of the revolutionary period. At the same time, it is a valuable historical source for researching the issue. This approach gives the possibility to understand the role of Ukrainians in the political life of Mariupol during that revolutionary period, their place in social processes in the Northern Azov region and in Ukraine in general. The coverage of the issues of the political everyday life of Ukrainians in the revolutionary processes of 1917 is important for forming the historical memory of contemporary young citizens of the Northern Azov region, especially in view of the fact that quite often they are still heavily influenced by the historical myths imposed by Soviet propagandists throughout more than a century.

The issue of political everyday life of Mariupol Ukrainians in the revolutionary processes of 1917 was not covered in outlined context. In Soviet times, this issue generally remained unaddressed by scholars due to ideological reasons. In the post-Soviet period, some aspects of the issue were partially addressed in works of Mariupol local historians (Bozhko, Buly, Hashenenko at all, 2006; Mazur 2007). V. Romantsov (2016; 2017; 2019) developed it in his studies at the modern scientific level, analyzing ethnopolitical and ethnocultural processes in Mariupol at the beginning of the democratic revolution of 1917, the events of the Ukrainian War of Independence of 1917 in Mariupol, the confrontation of the Ukrainian authorities with the Mariupol Bolsheviks, who organized an armed uprising in late 1917. However, no intelligence considered the participation of Ukrainians in the political life of Mariupol as a certain aspect of everyday life. 
The purpose of this study is to analyze the political everyday life of Mariupol Ukrainians in the revolutionary processes of 1917.

\section{Methodology}

The study of social processes of the revolutionary period in the Ukrainian environment of Mariupol in the context of their political everyday life is of considerable scientific interest. The history of everyday life is increasingly receiving recognition in the scientific knowledge of the Ukrainian past. The proposed scientific research is one of the first attempts to use the methodological aspects of the history of everyday life as one of the modern directions of historical studies for the analysis of political life of Ukrainians in the Northern Azov region, as long as the appeal to the history of everyday life in the historical reconstruction of social processes of the revolutionary period makes it possible to use the anthropological approach, methods of microhistory in this study. The history of everyday life encourages scientists to move away from coverage of solely political events, activity of political figures, and focuses on the political life of the region, on the participation of a certain population group in it. In this case, this refers to Mariupol Ukrainians. The works of contemporary Ukrainian historians contain theoretical developments on issues of everyday history. Methodological developments in the history of everyday life were analyzed by $\mathrm{O}$. Koliastruk (2011). O. Udod (2010) considered the place of everyday history as a direction of development of Ukrainian historiography. The source-study aspect of application of the scientific direction of the history of everyday life in the historical studies is covered in the studies of $O$. Vilshanska (2010). A modern view on the multidimensionality of everyday life in the context of the personal lifeworld was provided by O. Panfilov and L. Petrova (2019). Conceptual assessments of the political development of Ukrainians in the revolutionary period of 1917 are important for understanding of the issue were expressed by M. Kovalchuk (2015) and R. Pyrih (2020).

\section{Research and results}

Since the early modern times, Ukrainians had held an important place in the Northern Azov region, the administrative center of which in the eighteenth century was the Kalmius fortress (the palanka center in the Nova Sich), and since the end of the century - the Mariupol City, which historically became the continuation of this fortress after the resettlement of the Greeks from Crimea to the territory of the former Cossack Kalmius palanka, which was the implementation of Russian imperial policy in this strategically important region.

In the Mariupol polyethnic community that was formed at the beginning of the twentieth century, Ukrainians occupied a significant place. However, they were always regarded as an integral part of the "Russian people" by imperial authorities and the majority of Russian society and could not claim independent national-political development. Until the revolutionary events of 1917, the Mariupol Ukrainians had not been able to demonstrate their national identity under the Russian authorities' imperial integration policy, and during the First World War any such manifestations were suppressed.

During the war, the number of Ukrainians in Mariupol had grown at the expense of evacuated displaced persons and servicepersons of the 24th Reserve Infantry Regiment stationed in the suburbs, which increased their political potential in subsequent events of the Ukrainian War of
Independence (the Ukrainian Revolution). According to R. Pyrih, the Ukrainian War of Independence of 1917-1921 "demonstrated the desire of Ukrainians for national selfidentification, the capacity for independent state life, the formation of a political nation" (Pyrih, 2020). This was also demonstrated in the political life of Ukrainian residents of the administrative center of the easternmost district of the Yekaterinoslav Governorate.

At that time, Ukrainians were represented among different categories of residents of Mariupol, many of whom worked at the "Nikopol" and "Providence" factories. In the second half of March and during April, Ukrainian Society centers were created in the city and new members joined it. Ukrainian Society centers operated at the Zemsky Wheelchair and at the Oleksandrivka Men's Gymnasium. There was a daily registration to the Society (Mazur, 2007). On March 19, all interested were invited to the premises of the Lobachevsky Gymnasium to "find out how they perceive the events that are going on"1. A general meeting of the Ukrainian Society, which operated at the "Nikopol" and "Providence", was scheduled on March 25. It was planned to consider admission of new members and current issues ${ }^{2}$.

The political everyday life of Mariupol Ukrainians was greatly influenced by the leaders of the Ukrainian city movement, active members of the city "Prosvita" - a member of the Provincial Zemsky Assembly, a member of the City Public Executive Committee I. Kovalenko and a teacher of the parochial secondary school Serhiy Lypkivsky. The first of them was among three members of an editorial board of the newspaper "Mariupol Word" ("Mariupolskoe slovo"), which was the publication of the Mariupol Public Executive Committee (Mazur, 2007). Obviously, due to the efforts of I. Kovalenko, this newspaper provided a rather large amount of information not only about the Russian Democratic Revolution, but also about the events of the Ukrainian Revolution, the activities of the Ukrainian Central Rada.

I. Kovalenko's participation in the activities of the Mariupol Public Executive Committee contributed to the intensification of the political everyday life of Mariupol Ukrainians. He was among the representatives seconded by the Mariupol City Public Committee to attend the Mariupol Provincial Delegate Assembly ${ }^{3}$. By the resolution of the 7th meeting of the City Public Committee of March 13, 1917, Ivan Pantelievich was elected deputy head of M. Zemtsov, the head of this institution, in case of his absence ${ }^{4}$. According to I. Kovalenko's statement about the need to accelerate the organization of public education in Mariupol, a commission on public education was created under the City Public Committee. In April, he was also involved in the work of the health board ${ }^{5}$

In March, an important factor in the political everyday life of Mariupol Ukrainians was the newspaper "Mariupol Life" ("Mariupolskaya zhizn"), and after its publication ceased, and from April 1 until the end of 1917, the "Mariupol Word". They continuously provided information about the cultural and political life of Ukrainians in the city, about the political activity of the Central Rada and the progression of the Ukrainian Revolution in different regions of the country. This testified to a significant public request for this infor-

\footnotetext{
1 Mariupolskaya zhizn. 1917. 18 marta.

2 Mariupolskaya zhizn. 1917. 16 marta.

${ }^{3}$ Mariupolskoe slovo. 1917. 06 aprelya.

${ }^{4}$ Mariupolskaya zhizn. 1917. 17 marta.

${ }^{5}$ Mariupolskoe slovo. 1917. 06 aprelya.
} 
mation among Mariupol Ukrainians, which helped them navigate the complex social processes of the revolutionary period.

Immediately with the creation of the Central Rada in Kyiv, which headed the national revolution, the Ukrainian movement had become more active since March 1917 in Mariupol. Under the conditions of the euphoria that gripped the community of the city at the start of the revolution, the Ukrainian part of its inhabitants supported the implementation of democratic changes and participated in the creation of new power institutions. At the same time, Mariupol Ukrainians were increasingly emphasizing their nationality.

Mass events by democratic forces in support of revolutionary transformations were an important element of political everyday life at the beginning of the revolution. It is necessary to note representatives of the Ukrainian community among the participants of these events. In a mass demonstration in support of the revolution and social reforms that took place in the city on March 10, 1917, its participants carried banners not only in Russian but also in Ukrainian ${ }^{6}$. On April 18, the Interim Committee of the Ukrainian Society, called members of its organization for meeting on May 1 to participate in the celebration near the blue and yellow flag through the newspaper "Mariupol Word"7. According to the newspaper, a group of Ukrainians with the flag of "Free Ukraine" took part in various organizations of unions and national groups during the May Day ${ }^{8}$.

In the spring of 1917, the ideas of national-cultural and state revival spread quickly among the Mariupol Ukrainians. At that time, Ukrainian Society was increasingly combining cultural-educational and socio-political activities, becoming involved in the Ukrainian Revolution. The democratic processes that took place at that time in Mariupol contributed to it.

The appeal "To Ukrainian Citizenhood", published on May 18 in the newspaper "Mariupol Word", which reported that on April 6-8 the all-Ukrainian congress convened by the Ukrainian Central Rada was held, had a significant impact on the Ukrainian community of Mariupol. The congress united the Ukrainian parties "on the basis of demands for autonomy of Ukraine". According to the resolution of this congress, the Yekaterinoslav Ukrainian Governorate Rada was created, "which should unite all Ukrainian organizations and circles of our governorate, ... manage their activities in accordance with the instructions given to it by the Central Rada"9.

On May 21-22, the Ukrainian Governorate Congress was appointed. Serhiy Lypkivsky represented the Mariupol Ukrainian Society at this congress. On May 27, a general meeting of the Ukrainian Society "Prosvita" in Mariupol was scheduled at the premises of V. Ostroslavskaya Gymnasium, at which it was supposed to listen to the reports of the head of the Society S. Lypkivsky, as well as a frontline soldier on the organization of the Ukrainian army; reports on the activities of the theater commission and on refugees-Ukrainians (Mazur, 2007).

The Mariupol community was showing an increasing interest in the unfolding of the events of the Ukrainian Revolution. On May 30, the "Mariupol Word" published a Declaration submitted by the Ukrainian delegation to the

\footnotetext{
6 Mariupolskaya zhizn. 1917. 12 marta

7 Mariupolskoe slovo. 1917. 18 aprelya.

${ }^{8}$ Mariupolskoe slovo. 1917. 20 aprelya

${ }^{9}$ Mariupolskoe slovo. 1917. 18 maya.
}

Provisional Government and the Executive Committee of the Council of the Workers' and Soldiers' Deputies with editorial comments under the heading "Russian life"10.

During the Ukrainian Revolution in the summer of 1917 , the struggle for autonomy of Ukraine had intensified. AllUkrainian Peasant and Military Congresses which took place in the first half of June and declared unconditional support of the Central Rada's demands for nationalterritorial autonomy of Ukraine had a major influence on the political process in the country. On June 9, the "Mariupol Word" published a report on the All-Ukrainian Military Congress, the resolution of which criticized the unlawful prohibition on this congress by Russian Minister of Justice A. Kerensky and insisted that the Ukrainian people, after the overthrow of tsarism, had the right of free people to assembly congresses ${ }^{11}$.

Under the influence of the decisions of the All-Ukrainian Military Congress, the process of Ukrainianization of military units began, which was joined by military men of the 24th Infantry Reserve Regiment stationed in Mariupol. On June 8, Ukrainian soldiers were sent to the front, as the Mariupol newspaper reported. The members of Mariupol organization "Prosvita" came to accompany them, they staged a solemn mass meeting with the Ukrainian-language speeches at the station. The soldiers who were accompanied were given the Ukrainian national flag, and the Mariupol Enlightenment Choir sang "Testament" ("Zapovit") by Taras Shevchenko, "Shche ne vmerla Ukrayina" and some folk songs ${ }^{12}$

On June 11, the Mariupol newspaper published a speech by V. Vynnychenko at a meeting of the Central Rada, where he reported on the disappointing results of the Petrograd negotiations of the Ukrainian delegation, which he headed, with the ministers of the Provisional Government on National and Territorial Autonomy of Ukraine. Volodymyr Kyrylovych, who was extremely disappointed with the destructive position of Russian ministers, critically analyzed the situation in Russia, the lack of a government program for solving crisis issues and argued the prospects for the development of the Ukrainian movement ${ }^{13}$.

On July 7, the "Mariupol Word" published a report on the Second Universal of the Ukrainian Central Rada. Readers of the Mariupol newspaper were also informed about the meetings of the Central Rada. The speech of its head M. Hrushevsky was published. The newspaper quoted words by Mykhailo Serhiyovych that reflected the political compromise achieved in the negotiations with the Provisional Government ${ }^{14}$.

Under these political conditions, the Ukrainian political forces were formed in Mariupol. The initiative in this issue was taken by the Mariupol Society "Prosvita". On July 22, an announcement in which the board of the Society invited all members of the "Prosvita" to the general meetings was published in the "Mariupol Word". The agenda included questions about the election to the City Duma and the Province Rada. The announcement stated: "It is necessary to arrive - time is running out!"15. The Ukrainian Central Rada expressed interest in preparing the Duma elections in Mariupol. In connection with this, a request was made from Kyiv to the Mariupol City Council for the composition

\footnotetext{
10 Mariupolskoe slovo. 1917. 30 maya.

11 Mariupolskoe slovo. 1917. 9 iyunya.

12 Mariupolskoe slovo. 1917. 9 iyunya.

13 Mariupolskoe slovo. 1917. 11 iyunya.

14 Mariupolskoe slovo. 1917. 07 iyulya.

15 Mariupolskoe slovo. 1917. 22 iyulya.
} 
of the population which could take part in the elections in the city, as well as all the materials concerning the election of representatives of the Duma ${ }^{16}$.

From August 25 to September 10, 1917 courses in Ukrainian studies were organized by the Mariupol Province Zemstvo in Mariupol with the help of the Department of Public Education of the Yekaterinoslav Governorate Zemstvo. The courses were conducted in the Mariupol Disabled Persons' Home, and the director of this House V. Yu. Petrushevsky was the head of these courses. The lecturers were: S.O. Lypkivsky - Ukrainian language (20 lectures), Y.V. Yakush - geography of Ukraine (5 lectures), V.O. Bidnov - history of Ukraine (15 lectures), A.S. Sinyavsky - political economy (4 lectures), I.M. Truba and V.V. Blagonadiozhin - contemporary political issues and agitation (6 and 7 lectures respectively). Ukrainian books and newspapers were sold during the courses ${ }^{17}$.

The autumn of 1917 in Mariupol, as in Ukraine in general, turned out to be a very socially stressful time. During this period, there was a change in the vector of social development in Ukraine in general and in the Northern Azov region in particular, which was manifested in the election campaigns, filled with intense political struggle, to which the Ukrainian public and political forces were actively involved. On September 8 , elections to the Mariupol City Duma were held for the first time in a democratic way in the city. As a result of these elections, the board of the Duma had changed fundamentally in favor of the SRs and Mensheviks. In this election, Ukrainian political forces blocked with the Russian Socialist Revolutionary Party ${ }^{18}$. The representatives of the Ukrainian parties I. Kovalenko, T. Kovalenko and S. Lypkivsky were elected as the new City Duma speakers (Mazur, 2007: 32).

As a result of the Bolshevik October Revolution in Petrograd, the Provisional Government was removed from power. An important stage in the development of the Ukrainian Revolution and the process of revival of the statehood in Ukraine was the Third Universal of the Ukrainian Central Rada (UCR), proclaimed on November 7 (20), 1917. It declared the creation of the Ukrainian People's Republic (UNR), which meant the revival of the Ukrainian statehood.

From the moment of the UNR Proclamation, the authorities officially extended to the territory of Yekaterinoslav Governorate, including Mariupol and the province. But the way to implementation of this important legislative document, which had the nature of a constitutional act locally, in particular, in Mariupol Province, was not easy and was accompanied by the struggle of Ukrainian political parties for recognition of Ukrainian statehood by the local elite.

The full text of the Third Universal was published in Ukrainian by the newspaper "Mariupol Word" only a week after its adoption by the UCR on November 15, 1917'19, apparently under pressure from representatives of the Ukrainian community. The publication highlighted main provisions of the Universal: about authorities in Ukraine, its territory, the abolition of land ownership, labor issues, peace, abolition of the death penalty, the court, about selfgovernment and civil liberties, about food, the Constituent Assembly.

The following day, November 16, the city newspaper

\footnotetext{
${ }_{16}$ Mariupolskoe slovo. 1917. 29 avgusta.

17 Narodnaia zhyzn. Ekaterynoslav. 1917. 17 sentiabria.

18 Mariupolskoe slovo. 1917. 16 noyabrya.

19 Mariupolskoe slovo. 1917. 15 noyabrya.
}

published an extensive report on the meeting of the Mariupol City Duma devoted to discussing the issue of recognition of the UNR authorities. At this meeting, the question about the attitude of the Duma to the Ukrainian Central Rada was raised. The report was presented by the political leader of the Mariupol Ukrainians, the commissioner of the General Secretariat for Education, the Duma representative I. Kovalenko. He reasonably persuaded the Duma members to recognize the power of the UCR. However, even without supporting the Bolshevik Revolution in Petrograd, the latter were not ready to recognize the Ukrainian authorities immediately ${ }^{20}$. The solution of this fundamentally important political issue was delayed by the end of November 1917 .

On November 12, 13 and 14, 1917, elections to the AllRussian Constituent Assembly were held in Mariupol Province. The Mariupol Ukrainians used the political potential of this election to some extent. Representatives of the Ukrainian political community were in a separate list № 5. At the elections to the All-Russian Constituent Assembly, Ukrainians received more than 3,000 votes and, as a results of the election process, took third place in the city after the Bolsheviks and Russian SRs ${ }^{21}$. But this was not enough to consolidate the results of the Ukrainian Revolution and to assert the power of the UNR.

UNR leaders understood the importance of Mariupol for the Ukrainian People's Republic and assisted the Ukrainian political forces of the city. The Ukrainization of the 24th Reserve Infantry Regiment, which was stationed in Mariupol and supported the UNR authorities, was conducted. The Mariupol Province Ukrainian Rada, which, in contact with the Mariupol City Duma, exercised power in the city, relied on it and 200 haidamakas sent from Kyiv (Romantsov, 2019: 120). The question of its activities is not covered in historiography and needs further research.

The facts demonstrate that by the end of December 1917, Mariupol Ukrainians, who upheld democratic principles, had lost their political influence in conditions of increasing social contradictions, could not join forces with other democratic organizations of the region, and the Mariupol Bolsheviks had strengthened their influence among the workers and soldiers of the 24th Regiment through active propaganda. Relying on the formation of the Red Guards, on December 30, 1917, they disarmed soldiers and haidamakas and, for a time, took power in the city by military means (Bozhko, Buly, Hashenenko at all., 2006: 36).

\section{Conclusions}

Thus, considering the chosen issue, it can be concluded that under the influence of the revolutionary processes of 1917, the Mariupol Ukrainians for the first time had actively become involved in the political life of the city and Ukraine in general. This fact makes it possible to speak about their political everyday life. It was connected with awakening of national consciousness, gradual awareness of national identity, own political interests, attempts to defend them at the local and All-Ukrainian levels.

In the political everyday life of Mariupol Ukrainians, several stages, caused by the change of vectors of social development of the country by the processes of the Ukrainian Revolution, can be traced within 1917. The revolutionary events of the spring and summer of 1917

\footnotetext{
20 Mariupolskoe slovo. 1917. 16 noyabrya.

21 Mariupolskoe slovo. 1917. 16 noyabrya.
} 
were marked by attempts at democratic transformation at the All-Russian and Ukrainian levels, and demonstrated that at that time, the Ukrainian Revolution was in direct connection with the Russian Revolution, although in these processes there was a worsening of political contradictions.

This was reflected in the political everyday life of Mariupol Ukrainians to some extent. At the first stage, they supported the democratic slogans of the Russian Revolution, but at the same time formed their civic organizations, defined their leaders and began to form centers of Ukrainian political parties, intensifying political connections with the Ukrainian provincial associations of Yekaterinoslav region, strengthening their influence on the Ukrainian soldier mass of 24th Reserve Infantry Regiment.

The events of the Ukrainian Revolution had been widely covered on the pages of Mariupol newspapers "Mariupol Life" and "Mariupol Word". Newspaper publications informed the Ukrainian community of the city about the struggle of the Ukrainian Central Rada for the revival of national statehood and encouraged to intensify political activity at the regional level.

The next stage in the development of political everyday life of Mariupol Ukrainians was the period of the autumn of 1917. This time was marked by the completion of the formation of local centers of Ukrainian political parties, the participation of Ukrainians in the elections to the City Duma and to the Constituent Assembly. The Third Universal of the Central Rada, which proclaimed the creation of the Ukrainian People's Republic and extended its power to the territory of Yekaterinoslav Governorate, including the Mariupol Province, had a significant impact on the political life of Mariupol Ukrainians. The Mariupol centers of Ukrainian political parties, their political leaders took part in establishing UNR authorities in Mariupol and Mariupol Province. It was a difficult and controversial democratic process joined by some of the military men of the Ukrainian 24th Reserve Infantry Regiment. But further events showed that the process of the Ukrainian Revolution in Mariupol, as in Ukraine in general, was unfinished. Armed seizure of power by the Bolsheviks interrupted the political everyday life of Ukrainians which developed on a democratic basis. The analysis of this social phenomenon contains important lessons of history for our time. They claim understanding of Mariupol's unity with Ukraine, the need to strengthen this unity in the historical memory of contemporaries.

\section{REFERENCES}

Bozhko, R. P., Buly, T. Yu., Hashenenko, N. N. at all. (2006). Mariupol y ego okrestnosty: vzgliad iz XXI veka. Mariupol: Renata, 355 p. (In Russian).

Koliastruk, O. A. (2011). Metodolohiia istorii povsiakdennia. Visnyk Kharkivskoho natsionalnoho universytetu imeni V. N. Karazina. Ser.: Istoriia. 44: 8-21 (In Ukrainian).

Kovalchuk, M. (2015). Bytva dvokh revoliutsii: Persha viina Ukrainskoi Narodnoi Respubliky z Radianskoiu Rosiieiu. 1917-1918 rr. Vol. 1. Kyiv: Vydachnychyi dim "Stylos", 608 s. (In Ukrainian).

Mazur, P. Y. (2007). 1917 god. Mariupol: Ot fevralia do oktiabria. Istorycheskaya khronika. Mariupol: Izdatelstvo "Azovje" (In Russian)

Panfilov, O. Yu. \& Petrova, L. O. (2019). Bahatomirnist povsiakdennia u konteksti zhyttievoho svitu osobystosti. Visnyk Natsionalnoho yurydychnoho universytetu imeni Yaroslava Mudroho. 1 (40): 96-108 (In Ukrainian).
Pyrih, R. (2020). Ukrainska revoliutsiia 1917-1921 rr.: suchasnyi istoriohrafichnyi obraz ta doslidnytskyi potentsial. Academia. Terra Historiae. Studii na poshanu Valeriia Smoliia Vol.2. Kyiv: Institut istorii Ukrainy NAN Ukrainy, DU "Instytut vsesvitnoi istorii NAN Ukrainy": 117-132 (In Ukrainian).

Romantsov, V. M. (2016). Etnopolitychni ta etnokulturni protsesy v Mariupoli na pochatku demokratychnoi revoliutsii $1917 \mathrm{r}$. Istorychni uroky dlia suchasnosti. Visnyk Mariupolskoho derzhavnoho universytetu. Seriia: Istoriia. Politolohiia. Issue 16: 131-138 (In Ukrainian).

Romantsov, V. M. (2017). Ukrainska revoliutsiia. Podii 1917 r. v Mariupoli. Visnyk Mariupolskoho derzhavnoho universytetu Seriia: Istoriia. Politolohiia. 19: 47-59. (In Ukrainian).

Romantsov, V. M. (2019). Mariupolski bilshovyky na shliakhu do zbroinoho povstannia (lystopad - hruden 1917 r.). Pohliad cherez storichchia. Aktualni problemy nauky ta osvity: Zbirnyk materialiv XXI pidsumkovoi naukovo-praktychnoi konferentsii vykladachiv MDU. Mariupol: MDU: 120-122 (In Ukrainian).

Udod, O. (2010). Istoriia povsiakdennosti yak providnyi napriam ukrainskoi istoriohrafii. Kraieznavstvo. 3: 5-9. (In Ukrainian).

Vilshanska, O. (2010). Dzherela do vyvchennia povsiakdennoho zhyttia mist Ukrainy. Istoriia povsiakdennosti: teoriia ta praktyka. Pereiaslav-Khmelnytskyi: 87-89 (In Ukrainian).

\section{LIST OF REFERENCES LINK}

Божко Р. П., Були Т. Ю., Гашененко Н. Н. и др. Мариуполь и его окрестности: взгляд из XXI века. Мариуполь: Рената, 2006. $355 \mathrm{c}$.

Вільшанська О. Джерела до вивчення повсякденного життя міст України. "Історія повсякденності: теорія та практика": матеріали Всеукр. наук. конф., Переяслав-Хмельницький, 14-15 трав. 2010 р. Переяслав-Хмельницький, 2010. С. 87-89.

Ковальчук М. Битва двох революцій: Перша війна Української Народної Республіки з Радянською Росією. 19171918 рр. Т.1. Київ: Видачничий дім "Стилос", 2015. 608 с.

Коляструк О. А. Методологія історії повсякдення. Вісник Харківського національного університету імені В. Н. Каразіна. Сер.: Історія. 2011. Вип. 44. С. 8-21.

Мазур П. И. 1917 год. Мариуполь: От февраля до октября. Историческая хроника. Мариуполь: Издательство "Азовье", 2007. 40 c.

Панфілов О. Ю., Петрова Л. О. Багатомірність повсякдення у контексті життєвого світу особистості. Вісник Національного юридичного університету імені Ярослава Мудрого. 2019. № 1 (40). С. 96-108.

Пиріг Р. Українська революція 1917-1921 рр.: сучасний історіографічний образ та дослідницький потенціал. Academia. Terra Historiae. Студії на пошану Валерія Смолія: У 2-х кн. Київ: Ін-т історії України НАН України, ДУ "Інститут всесвітньої історії НАН України", 2020. Кн. 2. С. 117-132.

Романцов В. М. Етнополітичні та етнокультурні процеси в Маріуполі на початку демократичної революції 1917 р. Історичні уроки для сучасності. Вісник Маріупольського державного університету. Серія: Історія. Політологія. 2016. Вип. 16. С. 131-138.

Романцов В. М. Українська революція. Події 1917 р. в Маріуполі. Вісник Маріупольського державного університету Серія: Історія. Політологія. Вип. 19. 2017. С. 47-59.

Романцов В. М. Маріупольські більшовики на шляху до збройного повстання (листопад - грудень 1917 р.). Погляд через сторіччя. Актуальні проблеми науки та освіти: Збірник матеріалів XXI підсумкової науково-практичної конференції викладачів МДУ. Маріуполь: МДУ, 2019. С. 120122

Удод О. Історія повсякденності як провідний напрям української історіографії. Краєзнавство. 2010. № 3. С. 5-9. 
Володимир Романцов,

Маріупольський державний університет (м. Маріуполь, Україна)

e-mail: romantsov_v@ukr.net, ORCID 0000-0002-9019-4149

Наталя Романцова,

Маріупольський державний університет (м. Маріуполь, Україна)

e-mail: romantsova_n@ukr.net, ORCID 0000-0001-5032-1097

\section{ПОЛІТИЧНЕ ПОВСЯКДЕННЯ УКРАЇНЦІВ МАРІУПОЛЯ В РЕВОЛЮЦІЙНИХ ПРОЦЕСАХ 1917 р. (НА МАТЕРІАЛАХ ПЕРІОДИЧНОЇ ПРЕСИ)}

У статті на основі аналізу матеріалів періодичної преси висвітлено питання політичного повсякдення українців Маріуполя в революційних процесах 1917 р. Акцентується увага на інформаційній та організуючій ролі регіональної періодичної преси того часу, яка поряд 3 іншими аспектами містила повідомлення про політичну ситуацію в Україні, про діяльність українців Маріуполя, про політичний вплив на них Української Центральної Ради. Аналіз політичного повсякдення українців Маріуполя у революційних процесах 1917 р. дає можливість з'ясувати особливості цього суспільного феномену. Простежується зміна векторів повсякденного життя українців Маріуполя у політичній сфері протягом 1917 р. під впливом революційних процесів. Доведено, що політичне повсякдення маріупольських українців у швидкоплинних подіях революції визначалося під впливом кількох чинників: Українська революція, яка почалася у 1917 р. як складова Російської демократичної революції, а після прийняття III Універсалу утвердила національний характер; боротьба за відродження української державності, яка юридично була оформлена Універсалами Центральної Ради; активний процес формування української ідентичності на регіональному рівні, соціальні настрої в Україні загалом та Північному Приазов'ї й Маріуполі; загострення суспільних суперечностей та посилення військово-політичного протистояння на кінець року. Відзначається місце активістів українського руху в Маріуполі у політичному повсякденні революційної доби.

Ключові слова: політичне повсякдення; повсякденне життя; українці Маріуполя; періодична преса.

(C) Volodymyr Romantsov, Natalia Romantsova

Надійшла до редакції: 24.03.2020

Прийнята до друку: 10.04.2020 